\title{
Study of the physical and chemical characteristics of an immobilized lipase in the hydrolysis of fat waste
}

\author{
Viktoriia Skliar $^{1 *}$, Galina Krusir ${ }^{1}, K_{u z n e c o v a}$ Iryne$^{1}$, Valentyna Zakharchuk³ ${ }^{3}$ Myroslav Malovanyy ${ }^{4}$ \\ ${ }^{1,2}$ Odessa National Academy of Food Technologies, ${ }^{1}$ Departments of Ecology and Environmental Technologies, \\ Kanatnaya str., 112, Odessa, Ukraine 65039 \\ ${ }^{2}$ Departments of Microbiology and Nutrition Physiology Chair, \\ Kanatnaya str., 112, Odessa, Ukraine 65039 \\ ${ }^{3}$ Odessa National Economic University, Department of Expertise of goods and services, \\ Preobrazhenskaya str. 8, Odessa, Ukraine 65000* \\ ${ }^{4}$ Lviv Polytechnic National University, Department of Ecology and Sustainable Environmental Management, \\ Bandera str. 12, Lviv, Ukraine, 79013 \\ * corresponding author e-mail: vsklyar1993@gmail.com
}

Received: 19 December 2019 / Accepted: 8 April 2020

\begin{abstract}
A large amount of fatty waste from food enterprises accumulates in Ukraine, which represents a number of problems in their disposal. The main ones are formed during the production and processing of vegetable oils. Fat conversion usually occurs at high temperatures and pressures, while enzymatic hydrolysis is an energy-saving process.

Work highlights the main factors for obtaining immobilized biocatalysts, the conditions and methods for determining the activity and stability of immobilized enzymes. The work is devoted to the study of the physical and chemical properties of the immobilized lipase Rhizopus japonicus, namely the influence of the $\mathrm{pH}$ of the medium ( $\mathrm{pH}$ optimum $\mathrm{pH}$ stability) and temperature (thermal optimum, thermal stability). The objects of study were immobilized lipase Rhizopus japonicus, waste from the stage of demetalization of hydrogenated fat and activated carbon with a grain size of 2.0-2.8. It was revealed that for the immobilized lipase Rhizopus japonicus, the $\mathrm{pH}$ optimum value expanded with a shift from 7.0 to 6.5 , and a significant increase in $\mathrm{pH}$ stability was observed during prolonged incubation of the immobilized preparation. It was established that lipase immobilization leads to an expansion of the thermos-optimum, as well as stabilization of the enzyme during prolonged incubation at a temperature of $40^{\circ} \mathrm{C}$ and at higher temperatures $\left(60-80^{\circ} \mathrm{C}\right)$. The experimental results obtained indicate a higher stability of the immobilized lipase Rhizopus japonicus compared to native. The high activity and stability of immobilized lipase make it possible to recommend for bioconversion of oil and fat waste.
\end{abstract}

Keywords: immobilization, enzyme, lipase, waste, hydrogenated fat, waste sorbent, ecological biotechnology, oil and fat production, fat waste, $\mathrm{pH}$ stability, thermal stability.

\section{Introduction}

The production of oil and fat products in Ukraine is a significant sector of the agro-industrial complex. The main type of oil in the Ukrainian market remains sunflower $60 \%$ of the total market turnover. At different stages of the processing of plant materials, waste and by-products are generated that contain a significant amount of fatty ac- ids and related substances and are a valuable raw material for many industries. The process of hydrogenation of vegetable oils in oil and fat production is accompanied by the formation of large-scale waste, the main of which are spent sorbent from the stage of additional bleaching and spent catalyst, the fat content of which can reach more than $50 \%$. The hazardous properties of the waste are that the clay is able to ignite spontaneously upon contact with 
air. The simplest and most basic way to solve the problem of disposal of spent bleaching clay is a technology that involves their removal to landfills of solid waste. The most resource-efficient and environmentally friendly method is recycling with the production of a number of technical products, the technology of which uses the biotechnological method (Sklyar et al., 2019).

In the modern world, thanks to the rapid development of biotechnology, a scientific discovery in the field of enzymology, enzyme preparations have become widely used in many industries. Immobilized lipases can be used in almost all biotechnological processes to produce valuable products. In our case, this is the processing of hydrogenation waste from vegetable oils, namely the stage of demetalization.

Industrial processes increase the tendency to destabilize enzymes, reducing industrial life. The technology of enzyme immobilization is an effective way to overcome problem by increasing the catalytic properties of enzymes and improving the stability of the work (Keleti, 1990; Paiva et al., 2000). However, for the efficiency of enzymatic hydrolysis with already immobilized lipase, its physical and chemical properties should be investigated.

In this regard, an urgent problem is to increase the stability and effectiveness of lipase by immobilizing enzyme preparations, which increases the number of enzyme molecules per unit area, increasing the efficiency of enzymatic hydrolysis.

Oils contained in the waste products of the production of vegetable oils, is a low-calorie fuel. The disposal of such waste is accompanied by an active course of oxidation. In the hot season, they can spontaneously ignite, decay, emitan unpleasant smell of rancid oxidized fat. Methods for utilizing bleached clay involve its use in the production of bricks, expanded clay, cement, drying oil, aerated concrete, soap pastes, etc. The use of bleached clay is also possible as an additive in road bitumen, as well as in animal feed. A line for the production of biological products based on technic wastes of the oil and fat industry, a technology for controlled combustion using the received heat for technological needs is proposed. But the main way to utilize this waste is to bury solid waste at landfills (Krussir, 2010; Nur Royhaila Mohamad et al., 2015).

The feasibility of introducing technologies is determined by choosing the best economically viable technologies from the point of view of ecology, taking into account both economic and social aspects. Enzymatic hydrolysis technology is just such a technology. Most enzymes are quite unstable and industrial applications often impede the long-term operational stability and technically difficult process of restoration and reuse of the enzyme (Saifuddin \& Raziah, 2008).

The results of the studies (Sklyar et al., 2019) showed the effectiveness of the use of the enzyme lipase Rhizopus japonicus for hydrolysis of hydrogenated fat, and the physical and chemical properties of native lipase were studied (Skliar et al., 2019).

Immobilization of the enzyme was carried out, as low $\mathrm{pH}$ and thermal stability of the native enzyme were determined.Immobilization ensures rapid separation of the enzyme from the reaction mixture, the reaction is quickly stopped by removing the enzyme from the reaction solution, and the stability of the enzyme to temperature, solvents, and $\mathrm{pH}$ is improved (Cherno et al., 2009). The most effective method of stabilizing biologically active substances is immobilization on carriers of various nature, namely alumina, silica, porous glass, cellulose, zeolites, polyethylene, polypropylene, polystyrene, nylon, as well as activated carbon (Ramani et al., 2012). In our case, activated carbon, clays, and biopolymer matrices became the most effective matrix for immobilizing lipase. Activated carbon is resistant to bacterial, mechanical, chemical effects, has a developed surface, does not swell in liquids, the surface of activated carbon can be modified (Thakur, 2012; Hrydziuszko et al., 2014). An analysis of the works devoted to the study of biocatalysts based on activated carbon and lipase shows that the activity of the created samples is higher than for the native enzyme (Kumar \& Ray, 2014).

The method of physical adsorption has proven effective in applying lipase in continuous reactors to mesoporous activated carbon. Mesopores create a space for the enzyme that prevents lipase desorption from the surface of activated carbon and at the same time maintains activity.

In the course of previous studies, optimal conditions for sorption immobilization were selected: the carrier was impregnated with a $10 \%$ solution of the enzyme in $0.1 \mathrm{M}$ phosphate buffer solution, $\mathrm{pH} 7.0 \mathrm{pH}$ at $23^{\circ} \mathrm{C}$ using hydromodule (GM) 3 for agar-agar and karaginan, GM 1 for various clays (kieselguhr, ascanite, bergmeal) and GM 1.5 - for activated carbon and chitosan, the preparation was dried at a temperature of $40^{\circ} \mathrm{C}$.

It is shown that the use of activated carbon with a grain size of 2.0-2.8 as a carrier for lipase immobilization leads to the maximum preservation of the initial lipolytic activity. The optimal carrier: enzyme weight ratio was $1 \mathrm{~g}$ of biopolymer carrier per $500 \mathrm{mg}$ of lipase. From the obtained experimental data it follows that the rational conditions for the immobilization of Rhizopus japonicus are GM 1.5, temperature $25^{\circ} \mathrm{C}$, the duration of immobilization $15 \mathrm{~min}$ utes, the grain size of activated carbon, as a matrix is 2.0$2.8 \mathrm{~mm}$

After immobilization, the enzyme undergoes changes in physical and chemical properties, depending on the choice of immobilization method. The physical and chemical characteristics of an immobilized enzyme are stability - the ability to maintain catalytic activity under certain conditions. The stability is determined by the structure of the enzyme, as well as by the nature of its interaction with 
surrounding particles. The stability of the enzyme is also inferred from residual activity after incubation for a certain time, at a certain temperature and $\mathrm{pH}$.

Researchers are paying close attention to the effect of $\mathrm{pH}$ and temperature on lipase stability. Moreover, these two factors are of great practical importance and must be taken into account. For each enzyme, there are optimal values of quantities at which it exhibits maximum activity. The optimal $\mathrm{pH}$ and temperature of lipases from different sources vary within a fairly wide range. Despite the complex organization of the structure, lipases belong to stable enzymes and retain their activity in the temperature range of $30-60^{\circ} \mathrm{C}$ at $\mathrm{pH}$ from 4.0 to 8.0 . Some of the lipases act at sufficiently high temperatures $-55-70^{\circ} \mathrm{C}$. There are lipases known to be stable and active at $-20^{\circ} \mathrm{C}$ (Polygalina, 2003; Joseph et al., 2007; Singh \& Mukhopadhyay, 2012).

In previous studies, the lipolytic activity of the enzyme is retained by more than $30 \%$ compared to native, which is a high rate of activity conservation. However, for a more efficient implementation of the process of enzymatic conversion of waste by immobilized lipase, it is necessary to study the conditions under which the maximum enzymatic activity is manifested.

\section{Materials and methods}

The purpose of the work is to study the physical and chemical properties of the immobilized lipase Rhizopus japonicus for utilization of the fat fraction of waste.

The task of the work is to determine the $\mathrm{pH}$-optimum, $\mathrm{pH}$-stability and thermo-optimum, thermos-stability of the immobilized lipase.

The objects of study were waste of hydrogenation of vegetable oils, namely the waste of the stage of demetallization. As a substrate, a $40 \%$ emulsion of hydrogenated fat (PJSC Vinnitsa OFP) was used, which is the main component of these wastes, Rhizopus japonicus lipase produced by Enzim enterprise (Ladyzhyn, Vinnytsia region, Ukraine) and activated carbon with a grain size of 2.0-2.8 (First Gas Industrial Company LLC).

To provide the characteristics of the enzyme as a substrate, hydrogenated fat was used, which is the main component of its production waste.

Lipolytic activity was determined by the titrometric method of Ota and Yamada (Polygalina, 2003), which is based on the calculation of the amount of fatty acids formed during substrate hydrolysis. As a substrate $40 \%$ emulsion of hydrogenated fat, stabilized with polyvinyl alcohol was used. The amount of enzyme releases $1 \mu \mathrm{M}$ of acid from a $40 \%$ emulsion of hydrogenated fat at $37^{\circ} \mathrm{C}$ for 1 hour was taken per unit of activity. To a test tube containing $8-15 \mathrm{mg}$ of the sample, $1 \mathrm{~cm}^{3}$ of water, $0.1 \mathrm{~cm}^{3}$ of $0.1 \%$ solution of immobilized lipase, $0.8 \mathrm{~cm}^{3}$ of phosphate buf- fer ( $\mathrm{pH}$ of the medium corresponded to the $\mathrm{pH}$-optimum of lipase) was added and thermo-stated for $5 \mathrm{~min}$ at $37^{\circ} \mathrm{C}$. Then $1.0 \mathrm{~cm}^{3}$ of $40 \%$ emulsion of hydrogenated fat and polyvinyl alcohol thermo-stated under the same conditions, was added. Exactly after $1 \mathrm{~h}$ of incubation, the reaction was interrupted by the addition of $5 \mathrm{~cm}^{3}$ of $96 \%$ ethanol. In the control sample, an emulsion of hydrogenated fat was added after ethanol. Three drops of phenolphthalein solution were added to the control and experimental samples and titrated with $0.05 \mathrm{M}$ sodium hydroxide solution until light pink. The level of activity of the immobilized lipase was evaluated in conventional units by the difference in the amount of alkali, which went to the titration of the test and control samples during the hydrolysis of $40 \%$ emulsion of hydrogenated fat.

The activity of lipase was calculated by the formula:

$$
L A=\frac{\left(A-A_{1}\right)}{B} * 100
$$

where $\mathrm{A}$ - is the amount of $0.05 \mathrm{M} \mathrm{NaOH}$, which was used for titration of the prototype, $\mathrm{cm}^{3}$;

$\mathrm{A}_{1}$ - quantity of $0.05 \mathrm{M} \mathrm{NaOH}$, which was used for titration of the control sample, $\mathrm{cm}^{3}$;

$\mathrm{B}$ - amount of enzyme in the reaction mixture, $\mathrm{mg}$; 100 - coefficient for conversion to $\mu \mathrm{M}$; LA - lipolytic activity, U.

The $\mathrm{pH}$ optimum of the immobilized lipase was determined in such a way that a buffer solution with different $\mathrm{pH}$ values in the range of 2.5-12.0 was added to enzyme samples of equal activity and the enzymatic activity was determined.

The thermo-optimum of the immobilized enzyme was determined by studying for the same enzyme activity samples at a temperature of $20-80^{\circ} \mathrm{C}$ in the appropriate buffer corresponding to the $\mathrm{pH}$ optimum of enzyme.

To determine the $\mathrm{pH}$ stability, enzyme samples of equal activity were incubated at various $\mathrm{pH}$ values of 2.5-12.0 for $0-360$ minutes, then the $\mathrm{pH}$ of the solution was adjusted to the optimum value and the enzymatic activity was determined

The thermal stability of the immobilized lipase was studied in such a way that the enzyme samples equal in activity in the corresponding buffer solution, which corresponds to the $\mathrm{pH}$ optimum, were incubated at 20,37, 45, and $60^{\circ} \mathrm{C}$ for $0-360 \mathrm{~min}$, then the temperature was brought to $37^{\circ} \mathrm{C}$ and enzyme activity was determined.

\section{Results and discussion}

In previous works, the efficiency of the use of Rhizopus japonicus lipase in the hydrolysis of hydrogenated fat was 
shown (Sklyar et al., 2019), a technological scheme for the production of hydrogenated fat with the release of waste generated during its production (Skliar et al., 2019) was provided.

Figure 1 shows the scheme of processing waste with immobilized lipase.

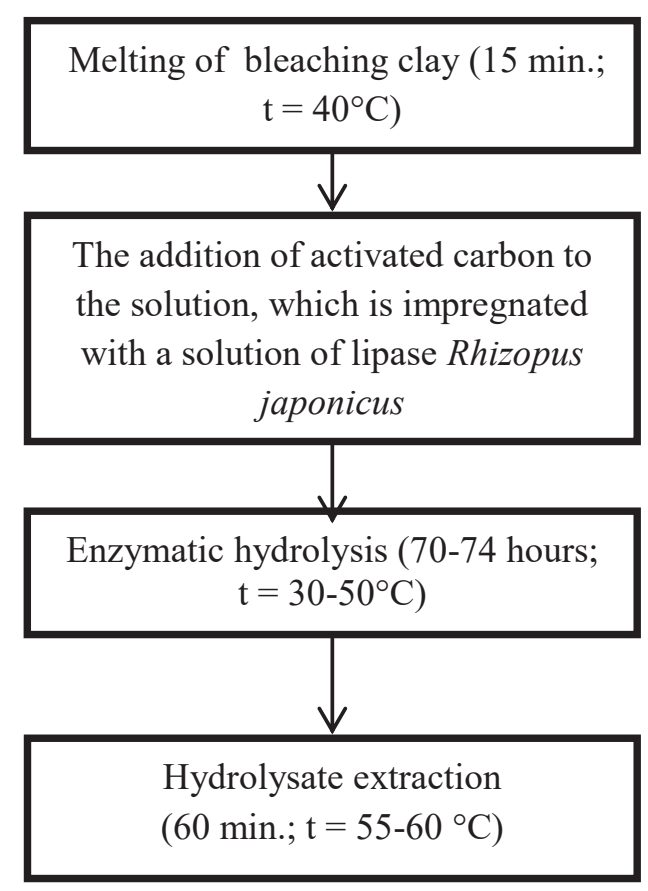

Figure 1. Schematic diagram of waste treatment with activated carbon immobilization

In order to optimize the conditions of fermentation of hydrogenated fat by immobilized lipase, a study of physical and chemical properties was carried out.

The nature of the carrier surface, depending on the content of the acidic or basic groups that are ionized, affect the $\mathrm{pH}$-optimum value of the immobilized enzyme. In this regard, there may be some degree of shift in the $\mathrm{pH}$-optimum value of the immobilized enzyme into the acidic or alkaline $\mathrm{pH}$ area, as well as expansion of the observed $\mathrm{pH}$-optimum area of the immobilized enzyme.

The $\mathrm{pH}$-optimum and $\mathrm{pH}$-stability of the immobilized lipase were studied under conditions similar to those of the native enzyme (Figs. 2 and 3 )

The $\mathrm{pH}$ optimum of the native enzyme was about 7 . As a result of immobilization, $\mathrm{pH}$ optimum expands and is in the $\mathrm{pH}$ range from 6.5 to 8 (Fig. 2).

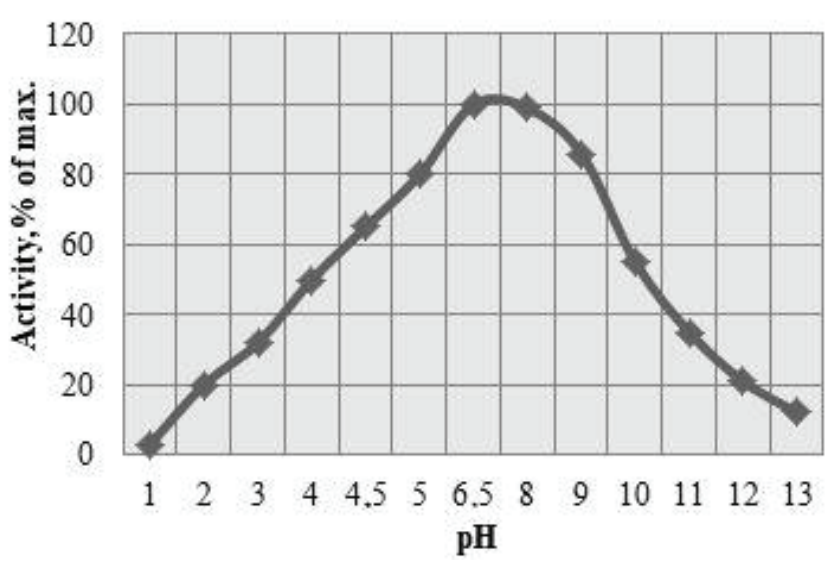

Figure 2. The $\mathrm{pH}$ optimum of Rhizopus japonicus immobilized lipase

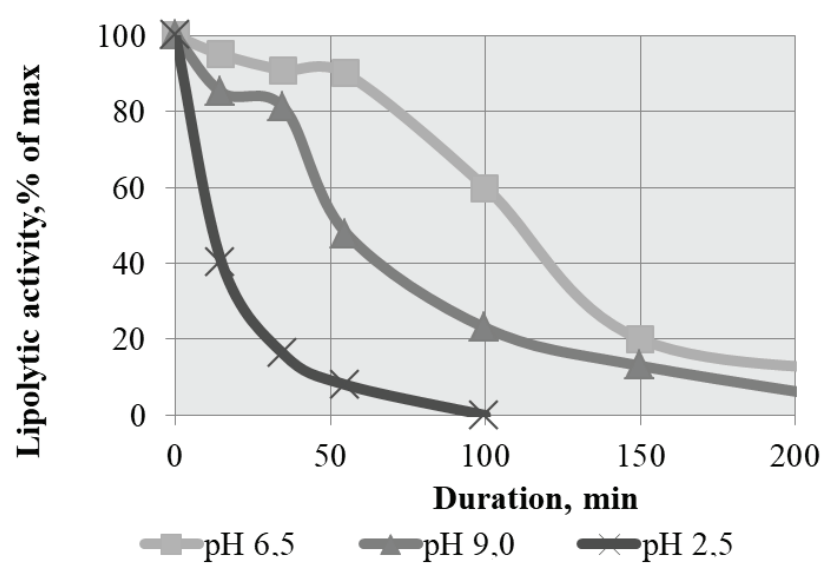

Figure 3. $\mathrm{pH}$ stability of the lipase Rhizopus japonicus (at $40^{\circ} \mathrm{C}$ )

Increase in $\mathrm{pH}$ stability compared to native was noted during prolonged incubation of the immobilized preparation with alkaline and acidic $\mathrm{pH}$ (Skliar et al., 2019). This allows us to predict effective functioning under real digestive conditions (Fig. 3), which may be due to the stabilization of the native conformation of the protein globule under the action of sorption forces, as well as the partial suppression of autolysis processes. In acidic medium ( $\mathrm{pH} 2.5)$, the activity of the immobilized enzyme is maintained from 50 to almost $100 \%$ for 25 minutes. In an alkaline medium ( $\mathrm{pH}$ 9), the activity of the immobilized enzyme in the complex is significantly reduced after $150 \mathrm{~min}$. incubating it under these conditions.

Immobilization of enzymes usually leads to an increase in thermo-optimum and thermos-stability due to varying degrees of strong fixation of the native conformation of the protein molecule and, accordingly, the difficulty of denaturing it with increasing temperature. 
The thermal optimum and thermo-stability of the immobilized preparation were studied under conditions similar to the native enzyme (Figs. 4, 5).

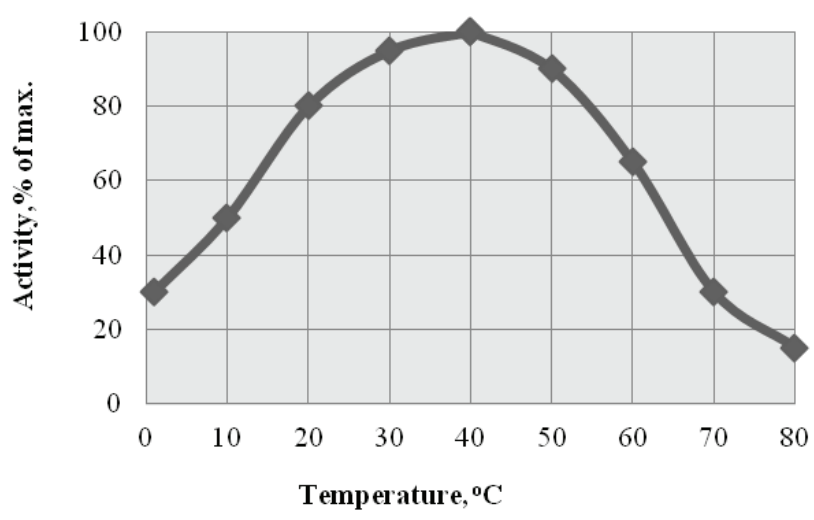

Figure 4. Thermal-optimum of immobilized lipase Rhizopus japonicus

As can be seen from the above data, immobilization of the lipase leads to expansion of the thermal-optimum compared to the native enzyme (Skliar et al., 2019) (Fig. 4).

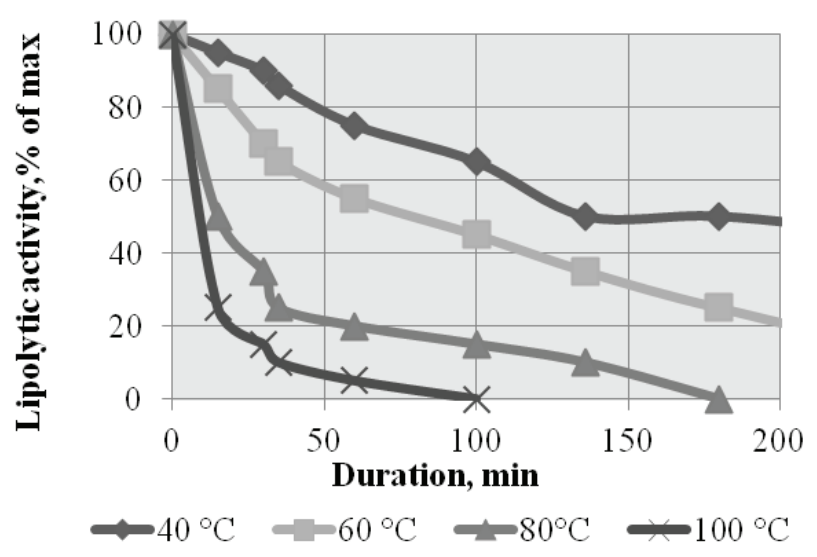

Figure 5. Thermal stability of Rhizopus japonicus lipase (pH 6.5)

Immobilization of the lipase leads to stabilization of the enzyme during prolonged incubation at physiological temperature $\left(40^{\circ} \mathrm{C}\right)$ and at higher temperatures (Fig. 5).

It was found that under such conditions, $80 \%$ of the activity of the immobilized enzyme persists for 50 minutes, whereupon value gradually decreases and after $150 \mathrm{~min}-$ utes it is $50 \%$. The activity of the immobilized enzyme in 175 minutes is completely lost at $80^{\circ} \mathrm{C}$. The total loss of activity at $100^{\circ} \mathrm{C}$ is 100 minutes.

\section{Conclusions}

The study shows that the selection of conditions contributed to the improvement of the process of enzymatic hydrolysis of the waste of hydrogenation of vegetable oils with immobilized lipase. Thus, the feasibility of immobilizing lipase on activated carbon has been proven. It is shown that immobilization contributes to the expansion of $\mathrm{pH}$ and thermal optimum.

It was determined that for the Rhizopus japonicus immobilized lipase, the $\mathrm{pH}$ optimum increased with a shift from 7.0 to 6.5 , and there was an increase in $\mathrm{pH}$ stability during prolonged incubation of the immobilized enzyme for alkaline and acidic $\mathrm{pH}$. This is due to the partial inhibition of the processes of autolysis and stabilization of the native conformation of the protein globule under the action of sorption forces.

It has been established that lipase immobilization leads to expansion of the thermo-optimum, as well as stabilization of the enzyme during long-term incubation at $40^{\circ} \mathrm{C}$ and at higher temperatures $\left(60-80^{\circ} \mathrm{C}\right)$.

It is established that at $40^{\circ} \mathrm{C} 80 \%$ of the activity of the immobilized enzyme persists for $50 \mathrm{~min}$., value gradually decreases and after $150 \mathrm{~min}$. is $50 \%$. Further use of hydrolyzed waste will make it possible to obtain new products, namely, an additive to rubber products.

\section{References}

Cherno N.K., Krussir G.V. \& Kovalenko O.V., 2009, Biocorrectors of etching processes. Monograph. Astroprint, Odessa, 257 pp. (in Ukrainian).

Hrydziuszko Z., Dmytryk A., Majewska P., Szymańska K., Liesiene J., Jarzębski A. \& Bryjak J., 2014, Screening of lipase carriers for reactions in water, biphasic and pure organic solvent systems. Acta Biochimica Polonica 61(1): 1-6.

Joseph B., Ramteke P.W., Thomas G. \& Shrivastava N., 2007, Standard review cold-active microbial Lipases: aversatile tool for industrial applications. Biotechnol. Mol. Biol Rev. 2(2): 39-48.

Keleti T., 1990, Fundamentals of Enzymatic Kinetics. Mir, Moscow (in Russian).

Krussir G., 2010, Prediction of effective methods of stabilization of plant biocorrectors. Grain Products and Feed 2(38): 15-1-8 (in Ukrainian).

Kumar D.S. \& Ray S., 2014, Fungal lipase production by solid state fermentation-An overview. J. Anal. Bioanal. Tech. 6(1): 1-10.

Nur Royhaila Mohamad, Nur Haziqah Che Marzuki, Nor Aziah Buang, Fahrul Huyop, \& Roswanira Abdul Wahab, 2015, An overview of technologies 
for immobilization of enzymes and surface analysis techniques for immobilized enzymes. Biotechnology, Biotechnological Equipment 29(2): 205-220.

Paiva A.L., Balcão V.M. \& Malcata F.X., 2000, Kinetics and mechanisms of reactions catalyzed by immobilized lipases. Enz. Microb. Technol. 27: 187-204.

Polygalina G.V., 2003, Determination of enzyme activity. Directory. DeLi print, Moscow (in Russian).

Ramani K., Karthikeyan S., Boopathy R., Kennedy L.J., Mandal A.B. \& Sekaran G., 2012, Surface functionalized mesoporous activated carbon for the immobilization of acidic lipase and their application to hydrolysis of waste cooked oil: isotherm and kinetic studies. Process Biochem. 47: 435-445.

Saifuddin N. \& Raziah A.Z., 2008, Enhancement of lipase enzyme activity in non-aqueous media through a rapid three phase partitioning and microwave irradiation. E-Journal of Chemistry 5(4): 864-871.

Singh A.K. \& Mukhopadhyay M., 2012, Overview of Fungal Lipase: A Review. Appl. Biochem. Biotechnol. 166(2): 486-520.

Skliar V., Krusir G., Zakharchuk V., Kovalenko I., Shpyrko T., 2019, Investigation of the fat fraction enzymatic hydrolysis of the waste from production of hydrogenated fat by the lipase Rhizopus japonicus. Food Science and Technology 13(1): 27-33.

Sklyar V., Krussir G., Lebedenko T., Khomich G. \& Kovalenko I., 2019, Research Study of the Conditions of Wastes Lipolysis Lipid Fraction. Journal of Ecological Engineering 20(3): 152-156.

Thakur S., 2012, Lipases, its sources, Properties and Applications: A Review. Int. J. Sci. Eng. Res. 3(7): 1-29. 